\title{
PHYTOCHEMICAL INVESTIGATION OF THE MEDICINAL PLANT MORICANDIA ARVENSIS L. FROM ALGERIAN SAHARA
}

\section{ABDELAZIZ BERREGHIOUA, ABDELKRIM CHERITI*}

Phytochemistry and Organic Synthesis Laboratory, Medicinal Faculty, Université Tahri Mohamed Bechar, 08000 Bechar, Algeria. Email: karimcheriti@yahoo.com

Received: 23 November 2017, Revised and Accepted: 19 March 2018

\section{ABSTRACT}

Objective: The aim of this research was to isolate and identify flavonoids extracted from the leaves of Moricandia arvensis.

Methods: The phytochemical screening reaction and thin-layer chromatography have been used to characterize the chemical groups, before they were identified by nuclear magnetic resonance.

Results: The leaves contain essentially flavonoids, tannins, cardenolides, saponins, and alkaloids. The phytochemical investigation of the water-acetone extract led to the isolation of five flavonoids derivatives, namely: 5,7-dihydroxy-3,6,4'-trimethoxyflavone (1); 5,7,4'-trihydroxy3,6,8,3'-tetramethoxyflavone (2); 3,3'4', 5,7- pentahydroxy flavanone (3); 3-glucosyl 3',4',5,7 tetrahydroxy flavonol (4); and kaempférol-3digalactopyranoside (5). The structures of 1-5 were identified by comparison of their spectral data with those reported in the literature.

Conclusion: In this work, it was possible to isolate and identify five flavonoids after fractionation of the hydroacetone extract from the leaves of the medicinal plant $M$. arvensis.

Keywords: Moricandia arvensis, Brassicaceae, Spectral data, Medicinal plants, Sahara.

(C) 2018 The Authors. Published by Innovare Academic Sciences Pvt Ltd. This is an open access article under the CC BY license (http://creativecommons. org/licenses/by/4. 0/) DOI: http://dx.doi.org/10.22159/ajpcr.2018.v11i6.23822

\section{INTRODUCTION}

South Algeria with its rich floral resources and ethnobotanical history is an ideal place to screen plants for biological activity and as a source of new pharmacological compounds [1-3].

Saharan plants are known by their resistance to several stress factors. Under extreme climatic conditions, they could constitute a large reservoir of new natural, safe, and effective structural moieties which work together exhibiting a wide range of biological activities $[1,3,4]$.

Moricandia arvensis belonging to Brassicaceae family is one of species native to the Mediterranean region and witch is cultivated as ornamental plants with purple, violet, and white flowers in Europe and America [5]. In traditional ethnopharmacopeae of Algerian Sahara, M. arvensis, known by the common name "Krom Jmal," is used for treating various diseases as rheumatism, syphilis, and scorbut [4] and provides food for camels [6].

A limited phytochemical works were reported for this species, and an indole derivative, glucosinolates, fatty acids, essential oils, and anthocyanins derivatives have been isolated and characterized [7-10].

In the aim of valorization of Saharan medicinal plants growing in Algerian Sahara and following our phytochemical works [11-16], on the secondary metabolite and bioactive substances, now we are interested in isolating the natural compounds from M. arvensis [11].

\section{METHODS}

\section{General experimental procedure}

Column chromatography was performed over silica gel 60 (Merck, particle size 230-400 mesh). Thin-layer chromatography (TLC) was carried out on silica gel 60 F254 plates (Merck, Germany). Ultraviolet (UV) spectra were obtained in methanol (MeOH) solvent with Unicam UV 300 spectrophotometer and Specord 200 Plus spectrophotometer.
Infrared (IR) spectra were obtained with a Thermo Nicolet Avatar 320 Fourier-transform-IR spectrophotometer. The nuclear magnetic resonance (NMR) spectra were taken on a Bruker Avance GP $250\left({ }^{1} \mathrm{H}\right.$ : 250 or $300 \mathrm{MHz} ;{ }^{13} \mathrm{C}$ : 75 or $125 \mathrm{MHz}$ ) spectrometer.

\section{Plant material}

M. arvensis was collected during full blossom (December 2009January 2010) from Oued Zouzfana (Algerian Sahara) and identified by Pr. A. Maarouf (University of Naama, Algeria). A voucher specimen is deposited in the herbarium of Phytochemistry and Organic Synthesis Laboratory under the number CA02/32.

\section{Extraction and isolation}

$150 \mathrm{~g}$ of dried leaves (grounded into powder) of M. arvensis were extracted with acetone-water (80:20 [v: v]) using Soxhlet apparatus, and reflux for $4 \mathrm{~h}$ was performed. This extract solution is filtered and evaporated (80\%) using a vacuum rotary evaporator. The aqueous extract was fractioned successively by three solvents: Diethyl ether $\left(\mathrm{Et}_{2} \mathrm{O}\right)$, ethyl acetate (AcOEt), and butanol $(\mathrm{BuOH})$ [17].

To purify and to identify the constituents of the diethyl ether fraction $(2.83 \mathrm{~g})$, ethyl acetate fraction ( $4.25 \mathrm{~g})$, and butanol fraction $(2.52 \mathrm{~g})$, some separations by liquid chromatography were achieved using a column in glass packed with a stationary phase of silica gel $(0.20 \mathrm{~mm})$; the mobile phases chosen for those separations are: Petroleum ether/ ethyl acetate $90 / 10,80 / 20,70 / 30,60 / 40,50 / 50,40 / 60$, and 20/80 for the chromatography analysis of the ethyl ether fraction; petroleum ether, ethyl acetate, mixture of chloroform-methanol for the analysis of the ethyl acetate fraction and finally hexan, ethyl acetate and $\mathrm{MeOH}$ for the butanol fraction analysis. All fractions were monitored by TLC. Fractions with spots of the same retention factor values were combined and chromatographed in appropriate solvent systems until pure compounds were obtained. 


\section{RESULTS AND DISCUSSION}

The experimental results of phytochemical screening of M. arvensis leaves revealed the presence of flavonoids, tannins, cardenolides, saponins, and alkaloids [4]. The presence of tannins is confirmed by positive reaction with ferric chloride $\left(\mathrm{FeCl}_{3}\right)$. Flavonoids test results showed a positive reaction in the presence of magnesium and $\mathrm{HCl}$. In contrast, the study indicated that reducing compounds were absent.

TLC analysis of the samples separated by liquid chromatography on column revealed the existence of two products ([1] and [2] in AcOEt fraction), two products ([4] and [5] in diethyl ether fraction), and one product ([3] in Butanol fraction). After several separations and analysis chromatographic, we regrouped the results in Table 1.

\section{Compound (1): - 5, 7-dihydroxy-3, 6, 4'-trimethoxyflavone}

$\mathrm{UV}_{\max }(\mathrm{MeOH}): 356,270 \mathrm{~nm}$; $(\mathrm{MeOH}+\mathrm{NaOH}): 357,271,280 \mathrm{~nm}$; $\left(\mathrm{MeOH}+\mathrm{AlCl}_{3}\right): 391,272 \mathrm{~nm}$; $\left(\mathrm{MeOH}+\mathrm{AlCl}_{3}+\mathrm{HCl}\right): 390,271 \mathrm{~nm}$; ( $\mathrm{MeOH}+\mathrm{NaOAc}): 355,278 \mathrm{~nm}$; $\left(\mathrm{MeOH}+\mathrm{NaOAc}+\mathrm{H}_{3} \mathrm{BO}_{3}\right): 356,276 \mathrm{~nm}$. IR (KBr): 3410.02, 2918.36, 1732.93, 1508.95, 1465.25, 1383.31, 1071.93, $837.03 \mathrm{~cm}^{-1} .{ }^{1} \mathrm{H}$ NMR $(\delta[\mathrm{ppm}]): 6.53(\mathrm{H}-8, \mathrm{~s}), 7.51(\mathrm{H}-2, \mathrm{~d}, \mathrm{~J}=8.2 \mathrm{~Hz})$, 6.91(H-3', d, J=8.4Hz), 6.91(H-5', d, J=8.4Hz), $12.8(\mathrm{OH}-5, \mathrm{~s}), 7.51\left(\mathrm{H}-6^{\prime}, \mathrm{d}\right.$, $\mathrm{J}=8.4 \mathrm{~Hz}$ ), 3.97(OMe, s). ${ }^{13} \mathrm{C}$ NMR (DMSO-d6, $\delta$ (ppm)): 155(C-2), 138 (C-3), 178 (C-4), 152 (C-5), 105 (C-5a), 131 (C-6), 157 (C-7), 94 (C-8), 152 (C-8a), 122 (C-1'), 130 (C-2'), 114 (C-3'), 161 (C-4'), 114 (C-5'), 130 $\left(\mathrm{C}-6^{\prime}\right), 56.40\left(\mathrm{CH}_{3}^{\prime}\right)$.

Compound (2): - 5, 7, 4'-trihydroxy-3, 6, 8, 3'-tetramethoxyflavone $\mathrm{UV}_{\max }(\mathrm{MeOH}): 352,272 \mathrm{~nm}$; $(\mathrm{MeOH}+\mathrm{NaOH}): 392,271,283 \mathrm{~nm}$; $\left(\mathrm{MeOH}+\mathrm{AlCl}_{3}\right): 383,272 \mathrm{~nm}$; $\left(\mathrm{MeOH}+\mathrm{AlCl}_{3}+\mathrm{HCl}\right): 382,271 \mathrm{~nm}$; $(\mathrm{MeOH}+\mathrm{NaOAc}): 352,276 \mathrm{~nm}$; $\left(\mathrm{MeOH}+\mathrm{NaOAc}+\mathrm{H}_{3} \mathrm{BO}_{3}\right): 352,276 \mathrm{~nm}$. IR (KBr): 3442.79, 2951.14, 1727.47, 1459.79, 1388.77, $1055.54 \mathrm{~cm}^{-1}$. ${ }^{1} \mathrm{H}-\mathrm{NMR}(\delta(\mathrm{ppm})): 7.80(\mathrm{H}-2, \mathrm{~s}), 6.98(\mathrm{H}-5, \mathrm{~d}, \mathrm{~J}=8.2 \mathrm{~Hz}), 12.45(\mathrm{OH}-5$, s), 7.68(H-6', d, J=8.2Hz), 4.01(OMe, s), 3.96(OMe, s), 3.84 (OMe, s). ${ }^{13} \mathrm{C}-\mathrm{NMR}$ (DMSO-d6, $\delta(\mathrm{ppm})$ ): 150.95(C-2), 135.2 (C-3), 176 (C-4), 152.2 (C-5), 102.9 (C-5a), 93.6 (C-6), 157.0 (C-7), 131.0 (C-8), 144.9 (C8a), 123.1 (C-1'), 114.8 (C-2'), 146.2 (C-3'), 147.2 (C-4'), 115.3 (C-5'), $121.2\left(\mathrm{C}-6^{\prime}\right), 56,41\left(\mathrm{CH}_{3}{ }^{\prime}\right), 59.8\left(\mathrm{CH}_{3}{ }^{\prime}\right), 60.2\left(\mathrm{CH}_{3}{ }^{\prime}\right)$.

\section{Compound (3): -3, 3', 4', 5, 7- pentahydroxy flavanone}

$\mathrm{UV}_{\max }(\mathrm{MeOH}): 351,249 \mathrm{~nm}$; $(\mathrm{MeOH}+\mathrm{NaOH}): 391,250,325 \mathrm{~nm}$; $\left(\mathrm{MeOH}+\mathrm{AlCl}_{3}\right): 381,249 \mathrm{~nm}$; $\left(\mathrm{MeOH}+\mathrm{AlCl}_{3}+\mathrm{HCl}\right): 361,251 \mathrm{~nm}$; $(\mathrm{MeOH}$ $+\mathrm{NaOAc}$ ): $265 \mathrm{~nm}$; $\left(\mathrm{MeOH}+\mathrm{NaOAc}+\mathrm{H}_{3} \mathrm{BO}_{3}\right): 361,264 \mathrm{~nm}$. IR (KBr): 3470, 2951, 2847, 1733, 1613, 1536, 1455.2, 1378, 1170, 1104, 620, 32 $\mathrm{cm}^{-1} .{ }^{1} \mathrm{H}-\mathrm{NMR}(\delta[\mathrm{ppm}]): 12.8(\mathrm{OH}-5, \mathrm{~s}), 6.17(\mathrm{H}-6, \mathrm{~s}, \mathrm{~J}=1.7 \mathrm{~Hz}), 6.37$ (H-8, $\mathrm{s}, \mathrm{J}=1.7 \mathrm{~Hz}), 7.55\left(\mathrm{H}-2^{\prime}, \mathrm{s}, \mathrm{J}=2.2 \mathrm{~Hz}\right), 6.83\left(\mathrm{H}-5^{\prime}, \mathrm{d}\right), 7.55\left(\mathrm{H}-6^{\prime}, \mathrm{d}, \mathrm{J}=2.2 \mathrm{~Hz}\right)$. ${ }^{13} \mathrm{C}$ NMR (DMSO-d6, $\delta$ [ppm]): 79.8 (C-2), 27.54 (C-3), 160.10 (C-4), 67.34 (C-5), 99.8 (C-5a), 96.30 (C-6), 156.88 (C-7), 93.01 (C-8), 156.80 (C-8a), 130.85 (C-1'), 116.10 (C-2'), 145.78 (C-3'), 145.81 (C-4'), 115.01 (C-5'), 118.60 (C-6').

\section{Compound (4): -3-glucosyl 3', 4', 5, 7 tetrahydroxyflavonol or 3-glucosyl quercetin}

$\mathrm{UV}_{\max }(\mathrm{MeOH}): 340,281 \mathrm{~nm} ;(\mathrm{MeOH}+\mathrm{NaOH}): 382,283,328 \mathrm{~nm}$; $\left(\mathrm{MeOH}+\mathrm{AlCl}_{3}\right): 370,281 \mathrm{~nm} ;\left(\mathrm{MeOH}+\mathrm{AlCl}_{3}+\mathrm{HCl}\right): 345,282 \mathrm{~nm}$; $(\mathrm{MeOH}+\mathrm{NaOAc}): 297 \mathrm{~nm}$; $\left(\mathrm{MeOH}+\mathrm{NaOAc}+\mathrm{H}_{3} \mathrm{BO}_{3}\right): 358,296 \mathrm{~nm}$. IR (KBr): 3437.33, 2956.6, 2847.34, 1732.93, 1486, 1465.25, 1383.31, $1366.92,1168,1104,625.3 \mathrm{~cm}^{-1} .{ }^{1} \mathrm{H}$ NMR $(\delta[\mathrm{ppm}]): 7.1(\mathrm{H}-2, \mathrm{~s}, \mathrm{~J}=2.1 \mathrm{~Hz})$, 6.98(H-5', d, J=8.2Hz), $12.7(\mathrm{OH}-5, \mathrm{~s}), 6.15(\mathrm{H}-6, \mathrm{~s}, \mathrm{~J}=1.5 \mathrm{~Hz}), 6.33(\mathrm{H}-8$, $\mathrm{s}, \mathrm{J}=1.5 \mathrm{~Hz}), 6.80$ (H-5, d, J=8.4Hz), 7.10 (H-6',d, J=2.1Hz), 7,55 (H-1", d, $\mathrm{J}=5.1 \mathrm{~Hz}$ ), 2,59 (H-2", d, J=7.1Hz), 2,70 (H-4", t, J=3.2Hz)., 3.20 (H-5", d, $\mathrm{J}=2.0 \mathrm{~Hz}$ ). ${ }^{13} \mathrm{C}$ NMR (DMSO-d6, $\delta[\mathrm{ppm}]$ ): 146.9 (C-2), 135.9 (C-3), 176 (C-4), 160.9 (C-5), 103.2 (C-5a), 98.3 (C-6), 164 (C-7), 93.5 (C-8), 156.3 (C-8a), 122.2 (C-1'), 115.3 (C-2'), 145.2 (C-3'), 147.8 (C-4'), 115.8 (C-5'), $120.1\left(\mathrm{C}-6^{\prime}\right)$.

\section{Compound (5): Kaempférol-3-digalactopyranoside}

$\mathrm{UV}_{\max }(\mathrm{MeOH}): 355,265 \mathrm{~nm}$; $(\mathrm{MeOH}+\mathrm{NaOH}): 375,283,327 \mathrm{~nm}$; $\left(\mathrm{MeOH}+\mathrm{AlCl}_{3}\right): 398,281 \mathrm{~nm} ;\left(\mathrm{MeOH}+\mathrm{AlCl}_{3}+\mathrm{HCl}\right): 398,282 \mathrm{~nm}$; $(\mathrm{MeOH}+\mathrm{NaOAc}): 358,280 \mathrm{~nm}$; $\left(\mathrm{MeOH}+\mathrm{NaOAc}+\mathrm{H}_{3} \mathrm{BO}_{3}\right): 358,296 \mathrm{~nm}$. IR
(KBr): 3371.78, 2940.21, 2874.65, 1667.37, 1601.82, 1503.49, 1459.79 , 1377.85, 1268.59, $1071.93 \mathrm{~cm}^{-1} .{ }^{1} \mathrm{H}-\mathrm{NMR}(\delta[\mathrm{ppm}]): 8.06(\mathrm{H}-2, \mathrm{~d}$, $\mathrm{J}=7.1 \mathrm{~Hz}), 6.88$ (H-3', d, J=7.1Hz), 6.88 (H-5', d, J=7.1Hz), 12.7 (OH-5,s), $6.17(\mathrm{H}-6, \mathrm{~d}, \mathrm{~J}=1.5 \mathrm{~Hz}), 6.39(\mathrm{H}-8, \mathrm{~d}, \mathrm{~J}=1.5 \mathrm{~Hz}), 6.80(\mathrm{H}-5, \mathrm{~d}, \mathrm{~J}=8.4 \mathrm{~Hz}), 8.06$ (H-6'd, J=7.1Hz), 5.34 (H-1", d, J=5.1Hz), 2.91 (H-2", m), 4.06 (H-6", m). 3.77 (H-1"', d, J=6.5Hz), 2.84 (H-2"', m), 3.95(OH-5"', m), 3.38 (H-6"', d, J=3.0Hz). ${ }^{13} \mathrm{C}-$ NMR (DMSO-d6, $\delta$ [ppm]): 159.3 (C-2), 133.2 (C-3), 177.32 (C-4), 161.16 (C-5), 103.63 (C-5a), 98.97 (C-6), 165.15 (C-7), 93.85 (C-8), 156.50 (C-8a), 120.84 (C-1'), 130.94 (C-2'), 115.08 (C-3'), 159.08 (C-4'), 115.08 (C-5'), 130.94 (C-6'), 102.89 (C1"), 71.11 (C-2"), 73.75 (C-3"), 69.87 (C-4"), 76.59 (C-5"), 67.15 (C-6").

The analysis of the ${ }^{1} \mathrm{H}$-NMR spectrum of compound (1) indicates the presence of three methoxyls at 3.96, 3.97, and $3.99 \mathrm{ppm}$, four aromatic protons: Two at $7.51\left(\mathrm{H}-2\right.$ ' and $\left.\mathrm{H}-6^{\prime}\right)$ and two others at $6.91 \mathrm{ppm}(\mathrm{H}-3$ ' and $\mathrm{H}-5^{\prime}$ '), and an ethylenic acid at $6.53 \mathrm{ppm}(\mathrm{H}-8)$. There is a signal at $12.8 \mathrm{ppm}$ relative to hydroxyl $(5-\mathrm{OH})$.

The ${ }^{13} \mathrm{C}$-NMR spectrum shows three signals at 56.10, 56.40, and $59.01 \mathrm{ppm}$, relating to primary attached oxygen (methoxyl) carbons, three signals at 94,114 , and $130 \mathrm{ppm}$ corresponding to tertiary carbons $\left(\mathrm{sp}^{2}\right)$, and ten quaternary carbons including a carbonyl type at $178 \mathrm{ppm}$ characteristic of a flavonoid. From the above spectral data, the structure is probably 5, 7-dihydroxy-3, 6, 4'-trimethoxyflavone (Fig. 1).

The study of the ${ }^{1} \mathrm{H}$-NMR spectrum of compound (2) gives the following indications: A signal as singlet at $12.45 \mathrm{ppm}$ with ${ }^{1} \mathrm{H}$ integration confirms the presence of a free $\mathrm{OH}$ in position 5 . A singlet at $7.80 \mathrm{ppm}$ with ${ }^{1} \mathrm{H}$ integration is attributable to $\mathrm{H}-2$ ', and two doublets at $7.68 \mathrm{ppm}$ and $6.98 \mathrm{ppm}(\mathrm{J}=8.2 \mathrm{~Hz})$ of ${ }^{1} \mathrm{H}$ integration each are attributable to $\mathrm{H}-6$ 'and H-5', respectively. These signals indicate that it is a disubstitution of the B ring. Four signals as singlets at $4.01,3.96,3.84$, and 3.83 ppm with ${ }^{3} \mathrm{H}$ integration, attributable to the methoxyl groups.

The data reported above are in agreement with those of the literature [18-20] and lead to the structure: 5,7,4'-trihydroxy3,6,8,3'tetramethoxyflavone (Fig. 1).

The IR spectrum of compound (3) shows an $\mathrm{O}-\mathrm{H}$ band in the vicinity of $3470 \mathrm{~cm}^{-1}$, and an absorption band at $1104 \mathrm{~cm}^{-1}$ which is characteristic of the C-O group of aliphatic ether. The vibration at $620 \mathrm{~cm}^{-1}$ notes the presence of a benzene ring, and an additional confirmation comes from the elongation bands of aromatic C-H located at the limit of the high frequencies of the aliphatic $\mathrm{C}-\mathrm{H}$ elongations.

The examination of the ${ }^{1} \mathrm{H}-\mathrm{NMR}$ spectrum shows: Two signals in the form of singlets at 6.17 and $6.37 \mathrm{ppm}(\mathrm{J}=1.7 \mathrm{~Hz})$ with ${ }^{1} \mathrm{H}$ integration, characteristic of the $\mathrm{H}-6$ and $\mathrm{H}-8$ protons, respectively; a singlet at $12.8 \mathrm{ppm}$, attributable to $\mathrm{OH}$ at position $\mathrm{C}-5$; and two other signals (singlet and doublet) at $7.55 \mathrm{ppm}(\mathrm{J}=2.2 \mathrm{~Hz})$ attributable to $\mathrm{H}-2^{\prime}$ and $\mathrm{H}-6^{\prime}$ [21]. The doublet at $6.83 \mathrm{ppm}(\mathrm{J}=7.1 \mathrm{~Hz})$ of $1 \mathrm{H}$ integration is attributable to $\mathrm{H}-5$ '.

Therefore, the most probable structure, based on the above spectral data, is 3,3 ; 4', 5,7-pentahydroxy flavanone (Fig. 1).

The investigation of the ${ }^{1} \mathrm{H}-\mathrm{NMR}$ spectrum of compound (4) shows the presence of two singlets at 6.15 and $6.33 \mathrm{ppm}(\mathrm{J}=1.5 \mathrm{~Hz})$ with ${ }^{1} \mathrm{H}$ integration each, characteristics of the $\mathrm{H}-6$ and $\mathrm{H}-8$ protons, respectively; a singlet at $12.7 \mathrm{ppm}$, attributable to $\mathrm{OH}$ at position $\mathrm{C}-5$; and two signals at $7.10 \mathrm{ppm}(\mathrm{J}=2.1 \mathrm{~Hz})$ in the form of a singlet and doublet with ${ }^{1} \mathrm{H}$ integration, attributable to H-2' and H-6' [22]. A doublet at $5.22 \mathrm{ppm}$ $(\mathrm{J}=5.1 \mathrm{~Hz})$ is attributable to the anomeric proton of a sugar bonded to the aglycone by a C-O bond (at position 3 ) because all other positions are occupied by protons; three doublets with $1 \mathrm{H}$ integration each at $3.70 \mathrm{ppm}(\mathrm{J}=7.1 \mathrm{~Hz}), 3.50 \mathrm{ppm}(\mathrm{J}=3.1 \mathrm{~Hz})$, and $3.61 \mathrm{ppm}(\mathrm{J}=2.0 \mathrm{~Hz})$.

It is noted that the values of the coupling constants are characteristic of vicinal couplings of protons of hydroxyl groups with $\mathrm{C}-\mathrm{H}$ groups. These observations indicate the presence of three hydroxyl groups in the sugar entity. 
Table 1: Results of liquid column chromatography

\begin{tabular}{llll}
\hline Compound & Rf (color in TLC) (eluent)* & & \\
\hline Compound (1) & 0.32 (yellow) (I) & 0.93 (yellow) (II) & 0.86 (yellow) (IV) \\
Compound (2) & 0.43 (yellow) (I) & 0.09 (yellow) (II) & 0.84 (yellow) (IV) \\
Compound (3) & 0.80 (blue) (I) & 0.04 (blue) (II) & 0.32 (blue) (IV) \\
Compound (4) & 0.90 (yellow) (I) & 0.43 (pale yellow) (II) & 0.32 (purple) (V) \\
Compound (5) & 0.59 (yellow) (I) & 0.43 (pale yellow) (III) & 0.20 (yellow) (V) \\
\hline
\end{tabular}

(Eluent): (I) B/A/W (4/1/5), (II) $\mathrm{CHCl}_{3} / \mathrm{MeOH} / \mathrm{H}_{2} \mathrm{O}$ (9/1/0.5), (III) MeOH/ $\mathrm{H}_{2} \mathrm{O} / \mathrm{AcOH}$ (20/1/1), (IV) $\left(\mathrm{CH}_{3}\right)_{2} \mathrm{CO} / \mathrm{H}_{2} \mathrm{O}$ (1/1), (V) Toluene/MeOH/EtOH/Petroleum ether $(2 / 1.5 / 1 / 0.5)$. Rf: Retention factor, TLC: Thin-layer chromatography

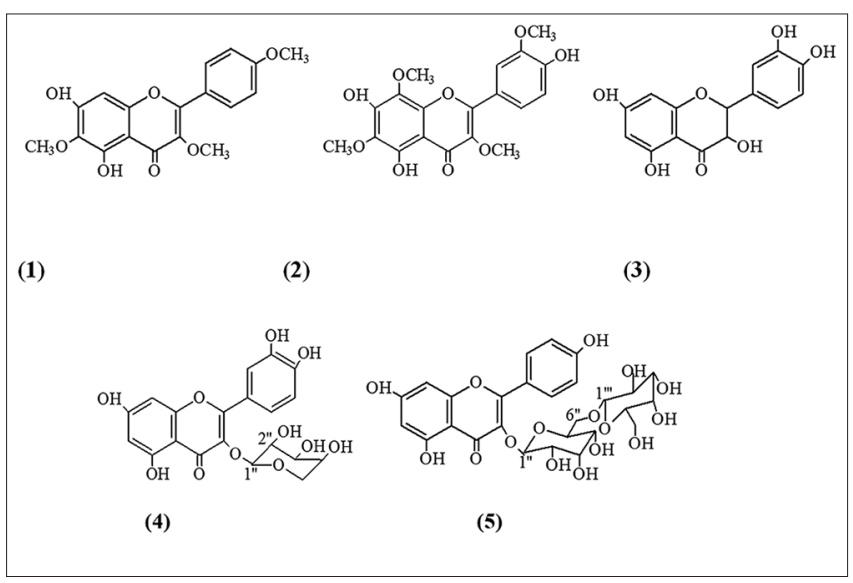

Fig. 1: Structures of flavonoids isolated from leaves of Mor1icandia arvensis

This hypothesis is supported by the presence of a triplet of doublet with ${ }^{1} \mathrm{H}$ integration at $2.59 \mathrm{ppm}(\mathrm{J}=7.1 \mathrm{~Hz})$ and two doublets at $2.48 \mathrm{ppm}$ $(\mathrm{J}=7.1 \mathrm{~Hz})$ and $2.70 \mathrm{ppm}(\mathrm{J}=3.2 \mathrm{~Hz})$. From the values of the coupling constants of this ring, it is clear that these signals are attributable to the three protons of the three $\mathrm{CH}$ groups of the three hydroxyls.

Also we noted a doublet at $3.20 \mathrm{ppm}(\mathrm{J}=2.0 \mathrm{~Hz})$, with $1 \mathrm{H}$ integration, thus from the previous results, this $\mathrm{C}-\mathrm{H}$ must be part of the sugar entity ring.

The IR spectrum of compound (5) shows absorption bands at 3371, 1667 , and $1503 \mathrm{~cm}^{-1}$ corresponding to the presence of hydroxyl, carbonyl, and a double bond.

The ${ }^{1} \mathrm{H}-\mathrm{NMR}$ spectrum of the compound (5) shows some signals characterizing a flavonoid skeleton of the flavonol type. In the fact, the doublets at 6.88 and $8.06 \mathrm{ppm}(\mathrm{J}=7.1 \mathrm{~Hz})$ with $2 \mathrm{H}$ integration each are attributable to H-3', H-5' and H-2', H-6'. The spectrum shows two signals at 6.17 and $6.39 \mathrm{ppm}(\mathrm{J}=1.5 \mathrm{~Hz})$ in the form of two singlets with ${ }^{1} \mathrm{H}$ integration, attributable to the $\mathrm{H}-6$ and $\mathrm{H}-8$ protons of A ring, respectively.

The proton signals of the sugar portion appear at $5.34 \mathrm{ppm}\left(\mathrm{H}-1^{\prime \prime}\right)$, $2.91 \mathrm{ppm}\left(\mathrm{H}-2^{\prime \prime}\right), 3.44 \mathrm{ppm}\left(\mathrm{H}-3^{\prime \prime}\right), 3.32 \mathrm{ppm}$ (H-4'), and $3.45 \mathrm{ppm}$ (H- 5").

The ${ }^{13} \mathrm{C}$-NMR spectrum shows signals which allow us to attribute all secondary carbons (C-H) of the flavonol skeleton: 93.85 (C-8), 98.97 (C6), $115.08\left(\mathrm{C}-3 ; 5^{\prime}\right)$, and $130.94\left(\mathrm{C}-2{ }^{\prime}, 6^{\prime}\right)$ and the carbons of the sugar portion at 2.89 (C-1 $\left.{ }^{\prime \prime}\right), 71.11\left(\mathrm{C}-2^{\prime \prime}\right)$, and 73.75 (C-3 '). The comparison of the ${ }^{13} \mathrm{C}$-NMR spectral data of this compound with those reported in the literature suggests that the glucose is attached to the $\mathrm{C}-3$ carbon insofar as the carbon C-3 and C-2 are at 136.1 and 147.5, respectively, if the carbon $\mathrm{C}-3$ is a carrier of a free $\mathrm{OH}$, and at 132 and 159.5 , if the $\mathrm{C}-3$ carbon is substituted [23-25]. Thus, all this spectral analysis makes it possible to say that the compound (5) is kaempferol-3-digalactopyranoside [23] (Fig. 1).

\section{CONCLUSION}

Plants of traditional medicine constitute a medical and economic potential of natural resources that provide the raw materials necessary for the production of drugs. Our works on ethnopharmacology of medicinal plants are complemented by phytochemical studies (screening, extraction, purification, and identification), for the valorization of medicinal species. In this context, it was possible to isolate and identify five flavonoids after fractionation of the hydroacetone extract from the leaves of the medicinal plant M. arvensis, hoping that our work allows a technical contribution to study and value plant by integrating it into the health and economic system of the country.

\section{IN MEMORIAM}

Article dedicated to the memory of Cheriti Bouhafs died on November $25^{\text {th }}, 2017$.

\section{AUTHOR'S CONTRIBUTIONS}

The experimental work was done by A. Berreghioua under the supervision of Pr. A. Cheriti.

\section{CONFLICTS OF INTERESTS}

The authors do not have any conflict of interest to declare.

\section{REFERENCES}

1. Cheriti A. Ethnopharmacological Study on Medicinal Plants in the Southwestern Algerian Region, Report CRSTRA, Algiers, Algeria; 2000

2. Gurib-Fakim A. Medicinal plants: Traditions of yesterday and drugs of tomorrow. Mol Aspects Med 2006;27:1-93.

3. Cheriti A, Belboukhari M, Belboukhari N, Djeradi H. Phytochemical and biological studies of Launaea Cass. Genus (Asteraceae) from Algerian Sahara. Curr Topics Phytochem 2012;11:67.

4. (a) Berreghioua A, Cheriti A, Belboukhari N. Preliminary phytochemical investigation of antibacterial extracts from Moricandia arvensis growing in Algerian Sahara. Nat Prod Ind J 2013;9:322-5; (b) Berreghioua A, Cheriti A, Belboukhari N. Flavonoids from the antibacterial extract of Moricandia arvensis L.growing in Algerian Sahara. Pharm Lett 2016;8:45-9; (c) Alouani I, Idrissi MO, Draoui M, Bouatia M. Review: From screening to application of moroccan dyeing plants: Chemical groups and botanical distribution. Int J Pharm Pharm Sci 2016;8:21-31.

5. Tatsuzawa F, Hatakeyama N, Takehara A, Nakajo S, Muraoka H, Ogawa S. Acylated anthocyanins in flowers of Moricandia DC. (Brassicaceae) Biochem Syst Eco 2015;58:38-42.

6. Longuo HF, Chehma A, Belkhier AO. Some botanical and nutritional aspects of dromedary pastures in Algeria. Mediterr Options Semin Ser 1989;2:47-53.

7. Belkhiri A, Lockwood GB. An indole derivative and glucosinolates from Moricandia arvensis. Phytochemistry 1990;29:1315-6.

8. Braham H, Mighri Z, Ben Jannet H, Abreu PM. Antioxidant phenolic glycosides from Moricandia arvensis. J Nat Prod 2005;68:517-22.

9. Zeraib A, Ramdani M, Lograda T, Chalard P, Figueredo G. Chemical composition and antimicrobial activity of essential oil of Moricandia arvensis L. (DC.). A J Plant Sci 2011;10:342-6.

10. Tatsuzawa F, Ito S, Sato M, Muraoka H, Kato K, Takahata Y, et al. A tetra-acylated cyanidin 3-sophoroside-5-glucoside from the purpleviolet flowers of Moricandia arvensis (L.) DC. (Brassicaceae). Phytochem Lett 2013;6:170-3.

11. Berreghioua A, Cheriti A, Belboukhari N. Antibacterial activity of Zilla macroptera extracts from Algerian Sahara. Phytochem Biosub J 2014;8:92-6. 
12. Yakoubi M, Belboukhari N, Sekkoum K, Cheriti A, Bouchekara M, Aboul-Enein HY. The chemical composition of essential oil of warionea saharae benth and Coss.(Fam. Asteraceae) from southern Algeria. Curr Bioact Compound 2015;11:116-21.

13. Rahmani S, Belboukhari N, Cheriti A. Phytochemical investigation of bioactive extract from endemic medicinal plant Limoniastrum feei (Girard) Batt (Plumbaginaceae). Asian J Chem 2014;26:365-8.

14. Chebouat EL, Dadamoussa B, Al-Gharabli S, Gherraf N, Allaoui M, Cheriti A, et al. Assessment of antimicrobial activity of flavonoids extract from Ephedra alata. Pharm Lett 2014;6:27-30.

15. Allaoui M, Cheriti A, Al-Gharabli S, Gherraf N, Chebouat E, Dadamoussa B, et al. A comparative study of the antibacterial activity of two chenopodiaceae: Haloxylon scoparium (Pomel) and Traganum nudatum Del. Res J Pharm Bio Chem Sci 2014;5:85-9.

16. Dahane-Rouissat L, Cheriti A, Marouf A, Reddy KH, Govender P. Molluscicidal activity of the saharian medicinal plants Limoniastrum feei and Launaea nudicaulis against the fresh water snail Lymnaea stagnalis. J Bio Envirn Sci 2015;7:242-8.

17. Belboukhari N, Cheriti A. Flavonoids of Limoniastrum feei. Res J Phytoch 2007;1:74-8.

18. Kupchan SM, Sigel CW, Hemingway RJ, Knox JR, Udayamurthy MS. Tumor inhibitors-XXXIII: Cytotoxic flavones from Eupatorium species. Tetrah 1969;25:1603-15.

19. Imron $M$, Worrapong $P$, Warangkana $C$, Puttinan M. Anti-radical activities of xanthones and flavonoids from Garcinia schomburgkiana. Int J Pharm Pharm Sci 2016;8:235-8.

20. Seghiri R. Research and Structural Determination of Secondary Metabolites of Centaurea: C. africana, C. nicaensis. (in French). PhD. Thesis, Mentouri University, Constantine. Algéria; 2005.

21. Fathy MS, Afaf H, Amal E, Shahira ME. An acylated kaempferol glycoside from flowers of Foeniculum vulgare and F. dulce. Molecules 2002;7:245-51.

22. Mabry TJ, Markham KR, Thomas MB. The Systematic Identification of Flavonoids. New York, Heidelberg: Spring-Verlag; 1970. p. $35-230$

23. Hing MH, Ruo YC, Lai KL, Franky LC, Yu H, Zhen-Yu C. Difference in flavonoid and isoflavone profile between soybean and soy leaf. Biomed Pharm 2002;56:289-95.

24. Awad MH, El-Egami A. The regioselectivity of glutathione adduct formation with flavonoid quinone/quinone methides is $\mathrm{pH}$-dependent. Chem Res Toxicol 2002;15:343-51

25. Felice S, Mario D, Irene D. Flavonoid glycosides of Barbarea vulgaris L. (Brassicaceae). J Agric Food Chem 2000;84:2659-62. 